\title{
A MANIFEST OF THE ENDANGERED PAST
}

\author{
Predrag Živković, University of Montenegro, sociollog@gmail.com
}

$10.31902 /$ fll.26.2019.18

UDK $930.85(497)$

\begin{abstract}
In this paper the author tries to represent the culture of memory (Kuljić 2006) which became independent in the post-socialist environment, becoming a kind of cultivated and privileged "refuge of forgetfulness" that aims to expel those traditions that are not welcome when constructing a society that is new and more vital in terms of identity. It is quite clear that these are the societies for which, not just socialism, but also other instances of historical encounter with their identity archetypes, represent the "wreck of memory," and the abyss of warning about creation, design and emigration into a new past that is comfortable enough for them. Is this the way that each of us should go? Is it the way of collective catharsis or a systemic and ideological exorcism, which systematically creates and persecutes all those who do not conform and do not get used to the climate of "The Damned Yard" (Симић 2014)? It seems that this condition forces a man to wake up from a passionate ideological coma and become a chronicler of life turmoil, i.e. "his own war" (Prilepin 2016).
\end{abstract}

Key words: culture of memory, identity, tradition, post-socialism, the past, Postmodern, Balkan;

\section{Introduction}

Themes regarding the domain of the culture of memory are not represented in only one social discipline or scientific research. They actually bring the phenomenon of the human spirit close to sociological, historiographical and anthropological, as well as sociolinguistic and philosophical views. When it comes to the culture of memory and remembrance, it is necessary to primarily outline a mechanism that grants it the right to maintain its belief in its competence and control over the process of thought-absorbing, equally maintaining the ethos and habitus of a community. This certainly does not imply the fact that the culture of memory is the refuge of linear history accustomed to the placidity of social development. Moreover, the culture of memory can be envisaged as closer to the cascades of overcoming its own past (Kuljić 2002), that is, a continuous effort to conserve and even complement the vitality of the spirit of a community in a waxed figuration with which a particular social group, due to such artefacts, would claim the right to the historical rubrics of its exceptionality. Dating from old times, this phenomenon is positioned as an accomplice and a devoted com- 
panion to all the decisive social debates when exhibiting piety and composing martyrdom on behalf of an unrepeatable social community. From the times of first civilisations to the postmodern epoch, the steps towards inauguration and overcoming the mortality of ethnos, social groups, and other forms of society, became a daily subject matter that needs to be solved, having at the same time physical, spiritual and symbolic mortality put aside. In all cultures, more or less, identical motives and ideological heroics could be traced. They all maintained the community's vigilance, never opening to the possibility of forgetting inside cyclic changes that can represent a metaphysical insufficiency and a path to total annihilation from the map of ontological presence. If judged by the views of the theoretically challenging and erudically conversant British historian Erik Hobsbaum, who has been influenced for the last decades by the social circumstances and that civil war at the sources of "orange illusions," as the brilliant Russian writer Zachar Prilepin notices (Prilepin 9), gradually became ever closer and clearer. Traditions of historically and genetically related peoples (here we refer to the peoples and the republics of the former SFRY), after cruel and unscrupulous yet ultimately unnecessary conflicts, became inconceivable day by day and sought to distance themselves from every thought on the former historical and spiritual symbiosis.

This landscape of analysis inevitably refers to theoretical approaches to the culture of memory that present and direct the course of our narrative in the most satisfactory manner. Assuming a historical perspective over the matter, it is our duty to present the compendium of those approaches that we consider, of course under the consent and review of the scientific board, to summarize and contain the impressions of the culture of memory and reminiscence of our own past. This also places the analysis under methodological conditions. Although these perspectives demand a special research petition that sometimes transforms into an introspective mechanism of study independent of the subject matter and the thematic commitment of the researchers, we will, as emphasized, strive to incorporate them in a wider panorama of the perception of a phenomenon which is, according to all assessment parameters, significant for sociological study of construction and processing of the past within the social frame of memory (Kuljić 2006; Albvaks 2013). For one type of endemic perception of post-Yugoslav (dis)balances, historiographer's choice focuses on the works of the eminent sociologist Todor Kuljić. Considering the map of his scientific creativity recognizable by theoreticians who deal with death studies and the culture of memory, we consider it highly important to open a scientificallybased study on these topics with his theoretical testimony, granting this way the methodological background and validity of this work. Our selection of the thematic framework centres on mechanisms of memory, remembrance and forgetfulness that are organically connected and form a strong register of indi- 
vidual and collective choices of existence with mythic contents of the past, as documented by the author.

These circumstances are most evident in countries in transition. However, a strong breakthrough of collective memory has morally shaped scientific history, and the pluralism of the images of the past has further relativized one [...]. In general, the use of the past is the reflection of political culture (J. Olick). What we remember and how we remember is quite reliably shown through our priority political values. (Kuljić 2006, 7)

This tendency to maintain continuity with the past can also disclose the reflection of one's own historical and political maturity. Therefore, it re-directs us towards the domain of the culture of memory in which it is possible to find latent traces of ideological intarsia. Accordingly,

the culture of memory studies the mechanisms of social transmission, design, maintenance and processing of the past, and develops insights of the collective and individual images of the past that people and groups in certain situations create, in order to interpret the present with the help of the past and produce a vision of future development. Its research priorities are composed of two general areas: (1) mechanisms for imposing the image of the past; (2) individual and group requirements that facilitate the acceptance of a particular past. $(2006,11)$

It is about retaining the credibility and recognition of a social group or a larger community who would find in those extracted contents the symbolism of their existence. From prehistoric to postmodern culture of memory, a long tradition of discontinuity has been created. In other words, various techniques of memory, with their epochal inauguration and triumphal twinkling, changed and distorted the significance of previous patterns of memory and remembrance. This implied a continuum that stretched from cosmological to the Age of Enlightenment and relativistic traditions of memory (Kuljić 2006). It is, therefore, interdisciplinary practicable to distinguish the following theories that claim the right to explore the past, and more precisely, point to the nature and anatomy of memory and remembrance. These are neurobiological, psychological and collective memory theories, with particular emphasis on socially constructivist and ideological-critical approach, as well as the theoretical considerations that formed around the theory of symbolic interactionism and hermeneutics (see more in: Kuljić 93). Moreover, we should not lose sight of Aleida Assmann's four formats of memory: "1) individual; 2) social; 3) political; and 4) cultural" (Asman 72). However, here we have no room to elaborate in detail the postulate of each 
of the above-mentioned theories separately. As we live in the postmodern era which preserves a distinctive constructivist approach in designing of the past, Todor Kuljić claims that it negates the contents of validity of the cognition of social reality (Kuljić 2006). It appears that the moment of consent and cognition given by this theoretician (along with our epistemological framework) is evident in his statement that

[...] social constructivists emphasise that remembering the past is always conditioned by the current significant structures of society. Not only do we forget, but we too create new memories [...] So, our vision of the past, not the past itself, is the frame of our memory (Schmidt). In this case, knowledge is not deprived of interest. (93)

This material also generates an epochal dispute between the postmodern and modern, that is to say, the postmodern denial of the great narratives (see more in Liotar 1988).

\section{"Blackmailed History"}

In this chapter, we intend to re-evaluate the interpretation of the past which in the Balkans has become favoured, and almost a new scientific discipline by the end of the $20^{\text {th }}$ century. We do not intend to condemn the use of the past in former socialist societies by malicious attitudes, but we will try to present the significance of the past for one nation as an integral element of its historical mapping. This opinion is also shared by Zdravko Deletić who points to the significance and formation of historical consciousness. For further understanding of the subject, it is necessary to emphasise that this theoretician gently follows the texture of historical consciousness. Not ignoring the possibility of its misuse or instrumentalisation, Deletić rightfully notes that history has become part of a national being, and a manner of its own cultural emanation (Делетић 2014). That also indicates the path to knowledge and sustainability of identity. In the seductive rhythm of contemporary globalization, this question plays the role of historical breviary, reminding the theoretician of the durability of his identity. Moreover, examples of abrupt historical changes made in order to infuse one society into the projected visions of the more advanced one the one that has overcome chickenpox of introvert and extrovert nationalism and chauvinism, are not isolated examples. This is proved by the efforts of the $20^{\text {th }}$ century history to break free from those (un)favourable ballasts. It should be more appropriate to point out the recurrences that appear as increasingly popular forms of social integration worldwide (we mean the awakening of extreme social movements) in the onset of economic and political crises (compare 
Kuljić 2002). It is not just about those societies that want to consolidate the wartorn national birth, as practiced in the Balkans, or to confirm the correctness of religious practice and confession of faith, as apparent among the Sunnis, the Shiites and the Alawites in the Middle East; but also about the tendency for the truth to emerge from the hypocrisy cloak of developed societies in which these phenomena of radical offense are increasingly frequent.

Now, what is to be done in case of the so-called surplus history disease? Do these situations need a break from a tumultuous history or is it a kind of collective psychotherapeutic catharsis? Sociologist Ljubiša Mitrović vividly speaks about the Balkan process that is suspected of numerous discomforts in culture that make it racially subordinated to Western values.

The Balkan conflictology is full of warfare epics, Martinism and the death culture. Within these geospatial areas, crosses and crossroads, borders and bridges, where the arches of different civilisations and cultures intersect, a "surplus history" is permanently being produced. Wartime culture and death culture, however, are no racial characteristics of the Balkan peoples, but the historical product of numerous deterministic settings that have shaped the epic identity, the collective character of peoples, groups, classes and elites. (Митровић 48)

It should be emphasized here that Mitrović is vigorously considering the ways in which this collective corpus is merged in times which differentiate various views of the past as more integral to history; depending on whether they are perceived from the standpoint of a lonely individual, an elite or a larger community (Митровић 2014). A passionate reader will not fail to notice an enviable picture of theoretical voices which become compatible and united in the background of the given topic. Beginning with Gurwitch, Marx and Nietzsche and their view of history and its objectivity, then Braudel and his enviable investigation of the place of respite between history and sociology, Ljubiša Mitrović clarifies the problem that we are trying to solve theoretically. Using the culture of memory and remembrance, this sociologist has established demarcation between what can be considered as mechanisms that facilitate the selection, and above all, the lifespan of memory and the iron law of remembrance of what would undermine the atavistic heritage of a community. As far as his analysis advocates the engagement of sociological science, it also penetrates deeply into historiography, disallowing the postmodern amnesia to embrace the abyss of forgetting the historical facts. As a witness to the past times, the culture of memory should possess the finest taste of resistance to everything that distorts the image of a society. As Mitrović warns, this may reflect the maturity of a community to uncompromisingly reject all seductive melodies that, lured 
by the opium of a grandiose superiority, lead to a whirlpool of inevitable confrontation with other communities. It appears that at the time of the epochal handling of postmodernism and imperialism, a mechanism of forgery and (dis) composure of the past were constructed inside the context of stigmatisation of small nations. Not long ago, the mystified face of revisionist historiography suspects historical victors and victims for being (un)conscious about the contradictions of the ideological epidemic of the $20^{\text {th }}$ century; leaving behind new epilogues to totalitarianism (Митровић 2014; Kuljić 2002). Fearing to remain on grounds of prediction and inconsistency, we will present our theses with Kuljićs authorisation, who has, in both sociological and lexical terms, been confirmed as a chronicler differentiating and categorising totalitarian movements and authoritarian leaders. We hope this to be a worthy explanation for the claim that intellectual circles were the devil's advocates in mitigating the condemnation of fascism and Nazism. With the emergence of socialism and its political vanity toward the opponents, a silhouette for a possible new totalitarian form will inevitably appear. Thus conditions for the anti-totalitarian illusion developed, concluding therefore the legacy of the Second World War, and later to have orthodox Marxists and followers of communist millenarianism latently placed under the totalitarian wing. The strive for abolishment is directed towards the imperial spirits, social movements and ideologies that sought to achieve their illusionist intentions.

Mitrović introduces us to the key concepts of his research findings. The word is about geoculture. Bearing in mind that our geoculture is based on the ethnographic settings of Jovan Cvijić, Ljubiša Mitrović does not lose sight of this enviable research heritage, and together with the starting points of the recognizable European perspectives of Braudel, Wallerstein, Kuznetsov and others, he accentuates the significance of this approach in contemporary sociology (see more in Митровић 2014; Wallerstein 1992).

In this sense, the concept of geoculture enables the analytical typology of a particular cultural heritage (tradition) and the contemporary living culture (in the broadest spectrum of its meaning) grow in a particular region. Developmental geoculture denotes cultural features inside the social evolution whereby a region (in sociological sense as one specific and concrete historical totality) differs from others in time and space. (54)

Carefully examining the theoretical templates of the analytical approach, Ljubiša Mitrović is seeking a place of insight in the world of literature where many magicians like Ivo Andrić and his native writers persuasively and picturesquely spoke about the virtues and flaws of the peoples that lived in the Balkans. These ethnographic and historical narratives infused into literary waves, 
were preserved from oblivion of the identities of peoples whose history was not favourable. The Balkans still preserve an introspective search for the roots of truth, which would secure some new subjugation in the name of new symbols and processes. This is, as Mitrović emphasises, a shaky defense of tradition, not only from the onslaught of globalisation, but also from the attacks of orthodox traditionalism and increasingly frequent, fictitious traditions (Hobsbom, Terens 2002). And at the very end of this complementary article, it is important to point out the words of this author and associate them with the sobriety of the culture of memory that will not ghettoise solely its ideologically close images of the past, but become tolerant and peaceful towards the ex-symbolically deported cultures (Митровић 2014).

Every valuable scientific approach to the culture of memory and remembrance must deepen the understanding of the endemic world of ideological matrices in order to present its own expertise in a proper way. These structures are often wrapped and strengthened by the blind faith of the masses, which thus give legitimacy to every totalitarian regime. Therefore, it is not necessary to ask for reasons that convinced George Orwell to write prologues for totalitarian societies. We find him ideologically and imaginatively close to Djuro Šušnjić (2008), who has recognised, by means of his encyclopaedic insights, the faces and traces of totalitarianism and various ideologies. Being exhausted from historical disasters he had witnessed, and always remaining theoretically vibrant, he sought to create a suitable climate for friendly encounters of cultures. Unfortunately, we are more inclined to summarise the history of the Balkans on the basis of daily reports or to falsify it in ideologically acceptable documentaries, disarming it from its historical rooting. Recognizing the intolerance and greediness of the societies of former Yugoslavia as their primary characteristic in militaristic upheaval at the dawn of the $20^{\text {th }}$ century, through the voices of caring and spiritually close scientific and literary brothers, Djuro Šušnjić warned of the ideological turmoil of nationalism and European negligence towards the Yugoslav trouble. Patches of Time (Танасковић 2014) have been tragically preserved in the sea-shells of memory on tides of nationalism. Relying on the influence and credibility of Orwell's thoughts on the power of their denial, Djuro Šušnjić refers to the sovereignty of thought and knowledge in the world of ideological manipulation. When it comes to the culture of memory, as well as the power of saying and confronting oneself and others with the doors of the past, it is necessary to avoid and discriminate political passions that hide the paths to the temple of understanding one's own identity. 


\section{The Passing of an Illusion ${ }^{1}$}

The influence of social structures on the flow of social memory and remembrance we find extremely important. As stated earlier in this epistle, having revealed the content and the course of thought, further elaboration will outline the "reading of the past" from the perspective of post-socialist societies, referring in particular to the societies of the former Yugoslavia. Hobsbawm's theory of fictitious traditions (Hobsbom, Terens 2002) ${ }^{2}$ was definitively established and recorded in historical volumes and sociological debates. It concerned the civil war in the former Yugoslavia, which, on the contrary, was justified by case studies and proved its hypothetical merit. What was noticeable with all newly emerging societies was the overcoming of the socialist past in order to revive and launch nationalist courts of Law. The extent to which nationalistic waves, that were created after the collapse of Yugoslavia, marked the 1990s, retaining so much in themselves after the rundown years of exogenous modernization (Dugin, 2009); they actually sought place of repentance and a refuge for red nostalgia (Bošković 2013) inside strong and insecure streams of postsocialist transformation.

The above-mentioned chronicler Zachar Prilepin (2016), who in our narration comes from the reticent lines of the perception of fugitive and suppressed identities that were forced out of the historical and spiritual boundaries into the mythical exile in a kind of confessional soliloquy (of his war chronicles), testifies precisely about the new readings of historical ruptures and (de)construction of the past, which form the profile of a new nation. Of course, it refers to recent events such as the civil war still taking place in Ukraine. As allies, who live in historical cracks of the new-born nations, and whose memory does not allow the luxury and privilege of remembering the common past, there exist rehabilitated memories that, like some dissidents or, say, apartheid, live in the ruins of memory of those nations, this author sees as the mirror of a spiritual suicide. From Kiev, to Moscowian Russia, as the embodiment of the Third Rome, today we have two nations created by cosmetic and ideological influences, with their closeness in all cultural and religious matters stigmatized, forgotten and deepened. With Zachar Prilepin we find the striking colours of what was perceived as a sense of rehabilitated ideology of fascism and Nazism in Ukraine. "All who fought communism must be Heroes and 'fathers of the nation"' (Prilepin 11). No comment is needed here. In liberated nationalist strivings, belonging to a new generation of Ukrainian citizens (which in the therapy of psychoanalytic Orangeism and comfortable idling on the cannabis of the Western ideological

1 Here we use Furet's book title The Passing of an Illusion in order to provide better insight and explanation of the communist past.

2 See more in: Živković, Predrag. "Ideological ornamentation of postmodern geography. The case of Zagreb and Podgorica." Annales, Series Historia et Sociologia. 28 (2) (2018): 399-414. 
course has freed itself of its collective-unconscious past) is based on a careful condemnation of communism (Prilepin 2016). Trying to slam the door to their past and to every single memory, not only during the Soviet period but for much longer, it becomes spiritually and organically difficult to eliminate the ages of permanence, wherefore Ukraine remained isolated in this cultural genocide inside that ideological experiment.

Similar example involves the former Yugoslavia.

In ethnically diverse area of the Western Balkans, as Todor Kuljić points out, the $20^{\text {th }}$ century's history was equally being invented and reconstructed (1) in order to distinguish related nations, and (2) to represent it to the world in a special missionary light. Nationalisms in different ways combine different forms of inventing the past. Reasons include (1) the explanation of the origin of the nation, (2) the method of its permanence, and (3) the historical 'sacrificial effect'. (Kuljić 191)

What needs to be underlined is that the political processing of the past of the new-born nations on the territory of the former SFRY was not created after the collapse of the former single state, but earlier, during the time of Yugoslavia. The question is what did actually suspend the blinded faith in the symbiosis of the community back then? It was definitely the secular religion that was to remove any memory from the religious tissue and fill out the new spiritual void with ideological support and promises. The seductiveness of this ideology, which was conceived as a great consolation to a disenfranchised man, flowering afterwards into totalitarian tendency due to its narcissism, is best testimonied through the writings of the French historian François Furet, who by his own acknowledgment once cherished empathy towards it. This refers to the communist ideology itself. In his epistemological experiment, Furet rather seductively and ingeniously calls the communist ideology the forerunner of the October Revolution (Furet 1997). Implemented and cultivated in the Leninist Parthenon, first in Russia, and later in the USSR, it relatively quickly, though apparently blindly, gained its political spark and legitimacy. From the former political passion and the cultivated animosity towards the bourgeois ideology, it has evolved over time into a red bourgeoisie. Furet suggests that communism and fascism appeared as two illusions to assumingly satisfy and encourage the defeatist instability of the disadvantaged working class. When concerning the philosophy of history, we recognise a motive familiar with sociological, philosophical and political discussions setting forth higher demands and desires to relinquish history to only one political theory, and to terminateits further course (Fukujama 1997; Dugin 2009). We cannot say though that liberal democracy triumphed over political theories. But we agree with Furet's statement: 
It seems that the peoples leaving Communism today are obsessed with denying the regime they lived in, although they bear the legacy of its habits and manners. The class struggle, the dictatorship of the proletariat, Marxism-Leninism, altogether disappeared under the advantage to what they had been mistaken for [...]. From the regime born in October, nothing survived except what they were the negation of. (Furet 19)

And this is one more reason that brings this theoretician closer to our theses. The extent to which the communist idea sought to challenge and overcome the past became an object of deconstruction and oblivion.

Postmodernism has largely encouraged the extinction of the tight social past. Although its presence dominates through the opening chapters, the following analysis will reveal its attitude towards post-socialist reality and its devotion to the Western parameters. Hereby we intend to search for particular ideal types of prevailing non-Western identities. Considering that the fall of the Berlin Wall and the USSR's post-socialist society found themselves in a state of ideological hangover, they quickly accepted the enacted patterns of future development and the reshaped history of their past. Kathrin Hörschelmann (2002) seems to recognize our effort and aspiration to find a theoretical equilibrium which, by nature, will be revisionist, not necessarily in the context of the glorification of only one discourse, but in objectification and mediation for creating a space that will not become the subject of ideological expropriation. This theoretician finds such analyses of postmodernism too predictable. Postmodernism does not fall into the nature of transformation but blindly recalls all opposing opinions that do not follow the patterns of liberalism. In the careful theorising of the post-socialist transformation, Kathryn Hörschelmann rightly underlines errors and conceptual dogmatism with theoreticians who had dealt with the communist past. A valuable analytical effort and evidence in the parsing of postmodernism is apparent here, although we cannot fail to notice that theories sometimes remain undefined.

Analyses of post-socialist transformation that seek to position it along the fault between modern past and postmodern future repeat a lot of homogenisation and universalism inherent in neoliberal end-of-history narratives, despite rejecting their optimism. A bird's eye view still eclipses the hybrid network of everyday social practices and 'small transformations' (Àkos Rona-Tas 1997) in grand theories of 'transition', while paying little respect to the evolving, unpredictable directions and effects of micro-social processes. (Burawoy and Verdery 1999). (Hörschelmann 57) 
Her scientific experiment on the post-socialist transformation related to everyday life of the inhabitants of East Germany, exhibits this ethnological account as a clear reminder that it is necessary to change the attitudes of the perception of postmodernism and the experience of newly emerging social structures (Hörschelmann 2002).

\section{A Pact with the Past}

At this moment it is necessary to provide theoretical and methodological background in order to give answers to the so-called drama industry of the Balkan societies based on similar examples. It is more complicated to say that it is a defective industry that has joined the phenomenological semantics and paradoxically, maintained the cultural industry that was once written by the Frankfurt School theoreticians Theodor Adorno and Max Horkheimer. Guided by the cognitive opus that has been developed in social sciences more than half a century ago, we will attempt to include it in a new theoretical march of the memory industry analysis. In this case we will call on Todor Kuljić again, who has recently offered the court of scientific jury a new framework for the interpretation of those social phenomena that can be said to be embroidered with symbolic loads of death. It captured our attention due to related themes and social phenomenon embodied in a not so old sociological and historical discussion that encompasses wider world's intellectual meridians. T. Kuljić's manuscript Finkelstein's debate on the Holocaust industry ${ }^{3}$ also introduces preliminary discourses on tanatopolytics and tanatosociology (Kuljić 2014). ${ }^{4}$ This essay, based on historical sociology and historioraphy, introduces us to a political folklore that draws its roots from biblical times, but which has never vanished from either theological or scientific discourses. The sketches of biblical days were embedded in a kind of narrative gown of the chosen people, altogether presenting a meditative, religious and political mortgage of the Jews. With the advent of the Second World War there was a terrifying attempt at the massive pogrom of the Jews with the systematically organized exorcism that was directed not only towards glorification of the racial supremacy of the Aryans, but also towards the instinctive devastation of any symbolic valuables of the Jewish people. Therefore we are trying to illustrate the horizons of a debate which appeared to expect the maturing of times in order to confront the victims and the suspects with the contextualisation of the events (Kuljic 2001). The place and event of the debate began with the conceptual and theoretical framework of the JewishAmerican politicologist, Norman Finkelstein. Through his book we notice politi-

3 See more in: Živković, Predrag. "Ideological ornamentation of postmodern geography. The case of Zagreb and Podgorica." Annales, Series Historia et Sociologia. 28 (2) (2018): 399-414.

4 See more in: Kuljić, Todor. Tanatopolitika / sociološkoistorijska analiza političke upotrebe smrti. Beograd: Čigoja štampa, 2014. 
cological dissidence in terms of science, and an apostate position in religious sense. However, its publication triggered a storm of comments. Most of them were of ideological nature, which presents a fruitful secondary material based on interpretations of a cohesive community.

Under the term 'Holocaust industry', the author does not signify the genocide over the Jewish people, but, remaining analogous to Adorno's term 'cultural industry', it denotes an ideological-organizational conglomerate of Jewish associations and lobbyists in the United States who recall the Nazi crime and Jewish suffering as cultural heritage in order to misuse it in their own financial and political goals. (Kuljić 2001, 290)

This was not a call for historical revisionism, because it was necessary to negate the existence of the Holocaust, and thus rehabilitate the Nazi regime of the time. After these shocking announcements, the response of the Jewish community and especially their intellectual elite could only be imagined, which threw this book into corners of conspiracy. That way Norman Finkelstein raised the ghosts of suspicion but also provoked the condemnation of the Jewish community in America, as well as the left-liberals in Germany, as Kuljić argues (2001). Although Finkelstein's study emerged on the basis of the Novik's book review, it nonetheless provided a sharper insight into Holocaust as the culture of memory, or tanatosociologically speaking, of an instrumentation of memory that relies on the lucrative desires of Jewish martyrdom. As much as it constitutes a systematic material for a single sociological analysis, it also offers a challenging synchronous method in analysing the conceptual definition and metamorphosis of the Holocaust from biblical determinism to the modern instrumentalisation of the term. It must be emphasised that the Holocaust has not always been benevolently observed, with a special piety of mourning and the desire to view this period of historical promenade as a unique monument to the tragedy of one nation.

The situation is changing with the US and Israel alliance in the late 1960s when the Holocaust prompted its career as an American cultural event. It is more about the consciously chosen collective memory, than about the upheaval of the suspended memory, which, being conceived as an ideological creation, serves as historical material in order to create a collective identity. $(2001,292)$

Kuljić distinguishes those segments of Finkelstein's study that point to tanatopolitical and tanatosocial moments rather than to the lexis of historical events. Essential elements of this critique relate to the sacralisation of the Ho- 
locaust, its martyrdom authenticity, as well as the political instrumentalisation of Jewish turmoil drawn to the pathos of

[...] the ritualization of memory. Jewish sufferings turned into a pseudo-interpretation of the events, reducing obviously the Holocaust to long-lasting supressed debates in American and German back pages. In addition, focusing on the Holocaust distracts the Americans from their genocide over the Indians, as Norman Finkelstein argues. (according to Kuljić 294)

Kuljic further notices that a specific trans-historic background for the suffering of the Jews through the Holocaust was to be created because the Holocaust represents a suitable sublimation and integration of the torn-apart tissue and a tendency towards a new de-secularisation (Kuljić 2001). History remembers abundance and lavish of similar practices of memory organisation (Kuljić 2006), which often try to challenge the sense of belonging and fertility (Simić 2014) with the mother culture, becoming a postmodern caricature and charade, i.e. initiating the sensors of the "Shoah business" (Kuljić 2001, 296). General conclusion to this thesis finds its support in the suggestion that: "As a universal symbol of mass suffering the Holocaust is easily interrelated to the marketplace of the past which did not exist" (2001, 307).

Choosing this type of narrative interpretation of the culture of memory and overcoming the past, and not avoiding to observe these phenomena from the perspectives of post-socialist societies, we are trying, through the paradigm of the Holocaust industry, to extend the boundaries of its ideological influence to similar examples that have become mythical footings in the Balkans, and on the American continent. Historical events often hide more layered meanings than those engraved in memorials. This became an ideological code for all societies that wanted to eliminate memories from any disturbing factors, even if they were written in the victim's language. Anyone who complies with these ideological orders becomes enchained by the forces of the Damned Yard's ruling system-as thoughtfully presented by Ivo Andrić, and subtly noted by Željko Simić:

we find in ourselves. This is the climate of an objectified spirit which, hermetically closed in its own obsessive variant of the communication with the system no longer distinguishes the blessing bestowed by genuine reality. (Симић 2014, 198).

However, we shall not terminate our theoretical cooperation with this theoretician. His importance and impact is evident through his creative experience. His theories prevail with the insights to the phenomena that have remained in our cognitive chronicles. That is where we face the long history of 
ratiocentrism development that is supported by the growing power of the postmodern technological system. The same system has enabled an unsustainable flow of globalisation in all its cascading models. Here we are interested in a seemingly simplified anachronism manifested through the term koyaanisqatsi which will turn out to stand for the cramp of the endangered past. To professor Simić the term koyaanisqatsi discloses much more than the meaning of a sluggish and artificially tortured reminder of the Hopi Indians. Considering how the author warns us about the interpretation of this term (life out of balance) since its translation into English remains questionable, we use it here as a research benefactor, i.e. the postmodern civilisation has changed skin colour to a contemporary individual, previously taking away his dignity in the form of a scalp, disarming him of every form of collective memory, encouraging him to the comfort of life out of balance (Симић 2009). Relying on the famous documentary achievement by Godfrey Reggio, Simić goes way further in analysing the concept that reveals the limits of a civilisational mutation. Eventually, following the axioms of a lucid analysis, we can say that:

Koyaanisqatsi is actually a mutated life of the psychic composure: it cannot be endangered by the aspects, it is actually the system [...] The Hopi know that koyaanisqatsi is not a single outbreak but a widespread psycho-social formation; it is not incidental, but consistently updated [...]. And the most important point: koyaanisqatsi, as a mutation, does not represent a kind of austere, non-homogeneous and a priori unsustainable acute exclusion, but the faithful takeover of relations onto which life inside of balance rests, defined through consistently contaminated demarcation as denial, i.e. out of balance. (Симић 2009, 13-15)

Regardless of the fate of modern man and society embodied in the concept of koyaanisqatsi, the Hopi Indians show mature alertness in perceiving its jurisdiction and its influence on the change of identity, through the constant tendency to maintain "the institutions of historicism that fix the identity blinded by the exclusion of living out of balance" $(2009,15)$.

\section{Conclusion}

Long and painful emancipation and exorcism, once used by colonial conquest, and now by the new civilisation that suppresses the spirit of paganism among the Natives (in Wallerstein's words), is an instrumentalised and imposed culture of memory and remembrance where the Natives need to adapt themselves to life beyond ordinary limits. This process has not been completed even in the twenty-first century. Moreover, it is only being perfected and encouraged 
in rising of a new cult of processing and constructing the past. The Balkans become the evidence to communism which experienced the same fate intended for its predecessors, all in order to pass triumphantly through historical straits. Liberalism therefore, due to its younger cousin neoliberalism, is also on the verge of oblivion. This led us to demonstrate the sustainability of ideological perspectives, regardless of whether they represent the interests of one social group, class or major formations and their political symbolism (Kuljić 2006). Taking into consideration the culture of memory, endemic diseases become transparent, and they practically determine the spirit of a community. That is one of the reasons why such analyses are usually abounding with burdens of disturbing past and above all, with surplus history of one's own.

\section{Works Cited:}

Albvaks, Moris. Društveni okviri pamćenja. Prevod: Olja Petronić. Novi Sad: Mediterran Publishing, 2013.

Asman, Alaida. "Sećanje, individualno i kolektivno". Kolektivno sećanje i politike pamćenja. Ur. Sládeček, Michal, Vasiljević, Jelena i Tamara Petrović Trifunović. Prevod: Sládeček, Michal, Vasiljević, Jelena i Tamara Petrović Trifunović. Beograd: Zavod za udžbenike, Ministartsvo prosvete nauke i tehnološkog razvoja, Institut za filozofiju i društvenu teoriju, 2015. 71-86.

Bošković, Aleksandar. "Yugonostalgia and Yugoslav Cultural Memory: Lexicon of Yu Mythology." Slavic Review. 72(1), (2013): 54-78. doi:10.5612/slavicreview.72.1.0054 (26. July, 2018)

Fukujama, Frensis. "Kraj istorije i poslednji čovek". Prevod: Branimir Gligorić, Slobodan Divjak. Podgorica: CID, 1997.

Furet, François. Prošlost jedene iluzije / Ogled o komunističkoj ideji u XX. stoljeću. Prevod: Radmila Zdjelar, Gordana V. Popović. Zagreb: Politička kultura, 1997.

Hobsbom, Erik i Terens, Rejndžer, ur. Izmišljanje tradicije. Prevod: Slobodanka Glišić, Mladen Prelić. Beograd, Biblioteka XX vek, 2002.

Hörschelmann, Kathrin. "History after the End: Post-Socialist Difference in a (Post)modern World. Transactions of the Institute of British Geographers." 27(1) (2002): 52-66. Retrieved from http://www.jstor.org/stable/3804455 (26. July, 2018)

Kuljić, Todor. "Finkelštajn - debata oko holokaust industrije." Sociologija. Vol. XLIII (No4) (2001): 289-308.

Kuljić, Todor. Prevladavanje prošlosti / uzroci i pravci promene slike istorije krajem XX veka. Beograd: Helsinški odbor za ljudska prava, 2002.

Kuljić, Todor. Tanatopolitika / sociološkoistorijska analiza političke upotrebe smrti. Beograd: Čigoja štampa, 2014. 
Kuljić. Todor. Kultura sećanja / istorijska objašnjenja upotrebe prošlosti. Beograd: Čigoja štampa, 2006.

Liotar, Fransoa-Žan. Šta je postmoderna. Prevod: Frida Filipović. Novi Sad: Bratstvo-Jedinstvo, 1988.

Prilepin, Zahar Nije tuđi rat / Jedan dan - jedna godina. Prevod: Radmila Mečanin. Beograd: Samizdat B92, 2016.

Šušnjić Đuro, Ribari ljudskih duša / Ideja manipulacije i manipulacija idejama. Beograd: Čigoja štampa, 2008.

Wallerstein, Immanuel. Geopolitics and geoculture / Essays on the changing world-system. Cambridge, University Press, 1992.

Živković, Predrag. "Ideological ornamentation of postmodern geography. The case of Zagreb and Podgorica." Annales, Series Historia et Sociologia. 28 (2) (2018): 399-414.

http://zdjp.si/wp-content/uploads/2018/11/ASHS_28-2018-2.pdf (04. December, 2018 )

Делетић, М. Зоран. "Историјска свест: фрормирање и деловање". Балканске синтезе. Vol. I (№1) (2014): 27-44. https://izdanja.filfak. ni.ac.rs/casopisi/2014/balkanske-sinteze-casopis-za-drustvena-pitanjakulturu-i-regionalni-razvoj (07. September, 2018)

Дугин, Г. Александр. Четвертая политическая теори / Россия и политические идеи XXI века. Санкт-Петербург: Амфора, 2009.

Митровић, Љубиша. "Историја, култура сећања и геокултура идентитета на Балкану". Балканске синтезе. Vol. I, №1 (2014): 45-61. https://izdanja.filfak.ni.ac.rs/casopisi/2014/balkanske-sinteze-casopis-za-drustvena-pitanja-kulturu-i-regionalni-razvoj (07. September, 2018)

Симић, Жељко. Антрополошка епистемологија епохе / Лакан и Дерида: напуштање рациоцентризма и обнова „криптичне традиције“. Подгорица, Универзитет „Медитеран“, 2009.

Симић, Жељко. Огледи из антропологије српске књижевности. Нови Сад: Прометеј, 2014.

Танасковић, Дарко. Белези времена / Појаве, догађаји, људи. Нови Сад: Православна реч, 2014. 


\section{MANIFEST UGROŽENE PROŠLOSTI}

Autor nastoji da u radu prikaže kulturu sjećanja (Kuljić 2006) koja se osamostalila u postsocijalističkom miljeu, postavši tako jednom vrstom kultivisanog i privilegovanog „utočišta zaborava“, koje stremi da izgna one tradicije koje nisu dobrodošle u konstruisanju novog i identitetski vitalnijeg društva. Sasvim je jasno, da je riječ o onim društvima za koje, ne samo socijalizam, već i druga mjesta istorijskog susreta sa svojim identitetskim arhetipovima, predstavljaju „,ruševinu sjećanja" i onaj bezdan upozorenja da se stvori, osmisli i emigrira u neku novu, za njih dovoljno komfornu prošlost. Da li je to put kojim svako od nas treba da krene? Da li je to put kolektivne katarze ili jednog sistemskog i ideološkog egzorcizma koji planski osmišljava i progoni sve one koji se ne povinuju i ne naviknu na klimu „Proklete avlije“ (Симић 2014)? Čini se, da je to stanje koje tjera čovjeka da se probudi iz pasionirane ideološke kome i da postane hroničar životnog previranja, odnosno, „sopstvenog rata“ (Prilepin 2016).

Ključne riječi: kultura sjećanja, identitet, tradicija, postsocijalizam, prošlost, postmoderna, Balkan. 